\title{
近代建造物の改修における付加価值 ADDED VALUE ON RENOVATION OF MODERN ARCHITECTURE
}

\author{
北川啓介*，中西正明**，村上心***，西川裕紀**** \\ 麓 和 善*****, 稲垣圭 亮****** \\ Keisuke KITAGAWA, Masaaki NAKANISHI, Shin MURAKAMI, \\ Hiroki NISHIKAWA, Kazuyoshi FUMOTO and Keisuke INAGAKI
}

\begin{abstract}
Modern period is age of diversification about building construction method, spatial composition, function and so on, because of added various value on modern architecture. Previous study on renovation method for use modern architecture prevail in internal and external case. But when we adapt renovation method to existent buildings, the method plays different role. The role caused "added value". This study use flowchart for analyze relationship between existent part and new part on renovation. As a result, we defined 2 factors caused by progressing the modern renovation method; the context concerning with the purpose of renovation exists or not, and the diversity about view of existent part.
\end{abstract}

Keywords : added value, renovation, modern architecture, purpose, process, flowchart 付加価值，改修，近代建造物，意図，過程，フローチャート

\section{1.はじめに}

近代注1) は，技術の進歩や，思想の変化により，建造物の建築工法 や空間の機能, 空間構成等が多様化した時期であり, その当時の文化, 歴史を反映するものである。そのため，近代建造物を再認識し，価 值注2)を与え，保存・管理して後世に伝承することは，その時代の文 化的，歴史的な伝統を守っていく上で重要といえる。そして，現代 社会において，近代建造物がどのような文化的価值をもつかを適格 に判断することで, その価值は時代を超えた有形, 無形の資産となり, 公共的で歴史的な価值となり得る。

近年，リノベーション，コンバージョンという用語が定着してい るように，過去の建造物の在り方が重要な問題として研究されてい るが，公共的で歴史的価值をもつ近代建造物においては，その保存 や建造当時の状態への復旧に焦点が当てられ，改修の目的も，免震 などによる耐久性の向上, 空調, 衛生, 電気, I T 対応設備の追加 や更新，地球環境保全のための省エネルギー化等といった目に見え ない部分の刷新が主目的とされがちである。

一方で，こうした近代建造物が，その改修を通じて，現代的価值 をもつ建造物として生まれ変わり, 現代建築として活用されている
事例も少なくない。

建造物の改修においては，設計者による個々の手法によって，改 修目的に即した価值のみでなく, 様々な価值が建造物に付加され得 るが，こうした付加価值が，歴史的価值をもつ近代建造物の現代に おける活用と深く関連していると考えられる。

歴史的建造物の現代における活用を研究するには，改修の目的と， 改修の手法，改修によって導かれる付加価值がどのような関係にあ るかを検討し分析することは重要であるといえる。そのためには, 既存部分や改修部分のみならず，既存部分と改修部分の相互の関係 も含めた視点をもつことも必要不可欠である。

本研究では，欧州と日本の近代建造物の改修事例を対象とし，近 代建造物の改修により新たに導かれる付加価值に着目する。改修過 程を一連の流れとして捉え分析することで, 形態や空間構成など, 既存部分の物理的な変化に加え, 改修に至る背景や要因, 改修を行 うことで導かれる付加価值を読み取り, 改修の目的, 改修の手法, 改修によって導かれる付加価值の関係を考察する。以上の視点から, 近代建造物の改修において導かれる付加価值の特性について論考す ることを目的とする。

\footnotetext{
* 名古屋工業大学大学院つくり領域 准教授・博士 (工学)

** 名古屋工業大学大学院工学研究科 博士後期課程 $\cdot$ 工修

*** 椙山女学園大学生活科学部 教授・博士 (工学)

**** (侏日総建一級建築士事務所 修士(工学)

$* * * * *$ 名古屋工業大学大学院ながれ領域 教授・工博

****** 三協立山(侏三協マテリアル社事業企画部＼cjkstart修士(工学)
}

Assoc. Prof., Tsukuri College, Graduate School of Engineering, Nagoya Institute of Technology, Dr. Eng.

Doctor Course Student, Graduate School of Engineering, Nagoya Institute of Technology, M. Eng.

Prof., Dept. of Human Environmental Design, Graduate School of Life Studies, Sugiyama Jogakuen University, Dr. Eng.

NISSOKEN Architects / Engineers, Inc., M. Eng.

Prof., Nagare College, Graduate School of Engineering, Nagoya Institute of Technology, Dr. Eng.

Sankyo Material-Company, Sankyo Tateyama, Inc., M. Eng. 


\section{2. 既往の研究}

既存建造物の活用に関する既往の研究として，小原による建物各 部位の構成順序と耐用年限の整合関係から, 建物のライフサイクル 中で行われる修繕・改良・模様替等の改修工事の円滑化に役立つ構 法手法を検討した研究 ${ }^{1)}$, 曽根による公共建築における転用事例の実 態調查から, 建造物の用途毎, 築年数毎, 規模毎の機能変更前後の 傾向を分析し, 既存建造物の計画手法を提案する研究 ${ }^{2 \sim 3)}$, 齊藤ら によるミラノ市所有の歴史的建造物の転用に着目し, カルロ・ペロ ガッリによる保存修復理論を基に, 改修事例の方針を比較検討する ことで，それぞれの改修方針に応じた建築的介入の特徴を導き出す 研究 ${ }^{4 \sim 5)}$, 松村らによる他国における集合住宅の再生事業の多様性, 事業推進組織の整備のあり方の日本との比較研究 ${ }^{6)}$, コンバージョ ン試設計の分析に基づいて, 事業性に影響を及ぼす主な評価項目と 建物属性の関係を明らかにした研究7)などが挙げられる。これらの 研究は全て, 既存建造物の物理的な変化を分類し, 既存建造物の用 途や空間構成との関係を明らかにすることを主題としている。また， 渋谷らによる欧州と日本の設計手法の傾向の体系化を行う研究 ${ }^{8)}$ は, 重要な先行研究だが, 改修手法を対象にしたものではない。

以上の研究に対して, 本稿は, 特に歴史的建造物に着目し, 既存 建造物の物理的な変化そのものを分類するのではなく, 改修におけ る社会背景から改修後に導かれる付加価值までを含めた過程を分析 する点で明らかに異なる立場をとっている。

\section{3. 研究の流れ}

研究の流れを段階的に示す。

1）建築専門誌『 $\mathrm{a}+\mathrm{u} \rrbracket \cdot 『 \mathrm{SD}$ ・『新建築』・『近代建築』9 14) 欧州と日本の近代建造物の改修事例を選定注3) する。

2）改修事例の説明文注4) から，改修において考慮された社会背景や 法律などの要因, 改修によって変化した形態や空間構成などの 物理的な要素, 改修によって新たに生まれた効果やイメージな どを改修に関わる要素として抽出, 分類する。そして, 改修事 例の説明文の内容, 論理展開からこれら改修に関わる要素ひと つひとつの相互の関係を抽出し，これを基に改修過程の一連の 流れを表すフローチャートを作成する。

3）作成したフローチャートの内容から, 改修計画の要求を示寸部 分を〈改修目的〉, 改修における建造物の物理的な変化としての 既存部分と改修部分の関係を示寸部分を〈改修手法〉, 改修を行 う過程, または改修後において新たに導かれた効果やイメージを 示寸部分を〈付加価值〉と定義する。そして, 改修過程において, 〈付加価值〉がどのように導かれているかを把握するため, 作成 したフローチャートの〈改修目的〉, 〈改修手法〉, 〈付加価值〉 のつながり方からく付加価值〉の生成過程を類型化する。

4）改修による建造物の具体的な変化を把握するため, 作成したフ ローチャートの内容の特に既存部分と改修部分の関係を示す部 分からく改修手法〉を類型化する。

5）改修によって，どのようなく付加価值〉がどのように導かれる のかを把握するため, 導かれたく付加価值〉の内容に着目し，3） で得られたく付加価值〉の生成過程の類型，4）で得られたく改 修手法〉の類型との関係を考察し, 近代建造物の改修において 導かれるく付加価值〉の特性について論考する。

\section{4. 改修過程の流れを表すフローチャートの作成}

\section{1 改修に関わる要素の抽出}

改修過程には, 改修において考慮された社会背景や法律などの要 因, 改修によって変化した形態や空間構成などの物理的な要素, 改 修によって新たに生まれた効果やイメージなど様々な要素が存在す る。そこで, 各改修事例の説明文の記述内容を基に改修に関わる要 素を抽出した結果，［改修背景］，［自然環境］，［思想］，［空間概 念 ，［周辺環境］, [位置 ], [活動空間 ], [スケール ，［物体］, [ 効果 ] の 10 種類の分類を得た（表 1 ）。

表 1 改修に関わる要素

\begin{tabular}{|c|c|c|}
\hline 分類 & 定義 & 例 \\
\hline [改修背景] & 改修に至る背景 & 法律, 歴史的事実 \\
\hline [自然環境 $]$ & ある部分が備えている自然の状態や現象 & 光, 明るさ, 樹木, 青み \\
\hline [思想 $]$ & 改修のあり方や計画意図 & オリジナルを尊重 \\
\hline [空間概念] & 空間で感゙゙感覚や㭱象 & 厳格さ,透明性,雰囲気 \\
\hline [周辺環境] & 敷地や周辺の立地特性 & テムズ川,シャンゼリゼ通り \\
\hline [位置］ & 方位や部位 & コーナ一部,正面,全面 \\
\hline [活動空間] & 機能や用途, 利用者の種類や活動の状態 & 議事,風景,パブリックな空間 \\
\hline [スケール] & 広さ, 尺度などのスケール & 高さ,幅,角度,柱スパン \\
\hline [物体 $]$ & 敷地内の物理的な要素 & 床,壁,柱,ガラス \\
\hline [効果］ & 建築的,空間的な効果 & アクセスしやすくなる \\
\hline
\end{tabular}

\section{2 改修に関わる要素の関係の抽出}

各改修事例から抽出した改修に関わる要素は, 改修過程において 単独もしくは，相互に関係をもちあう。壁の削除や床スラブの付加 といった躯体操作, 外部空間の内部化や内部空間の変化, 改修する 位置といった空間的操作，更に，建造物に関連する歴史的事実や法 律といった改修の要因など, 様々な要素が相互に関係するといえる。 そこで, 各改修事例の説明文の記述内容を基に改修に関わる要素ひ とつひとつの相互の関係を抽出した結果, 要素単独, もしくは, 相 互の関係として 22 種類の分類を得た（表 2 ）。

表 2 改修に関わる要素の関係

\begin{tabular}{|c|c|c|}
\hline 分類と表記 & 定義 & 例文 \\
\hline 削除 $[\overline{\mathrm{A}}]$ & Aを削除する & 増幅部をカットする \\
\hline 保存 $[\overline{\mathrm{A}}]$ & Aを残す & 全体のヴォリュームバランスをを保つ \\
\hline 加工 $[\overline{\bar{A}}]$ & Aを加工する & ガラス面を細工寸る \\
\hline $\mathrm{A}$ 拡大 $\mathrm{B}$ & AをBまで増やす & 8万席から10万席に挔張する \\
\hline A_縮- $-B$ & AをBまで減らす & 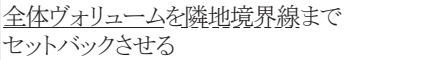 \\
\hline A_変換 $B$ & $\mathrm{~A}$ A Bに変える & 工場を美術館に変更する \\
\hline$A$ A_可視、B & AからBを見せる & 2階レベルから議事風景を見せる \\
\hline A_復元、B & 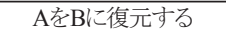 & 回廊に円形柱を復元する \\
\hline A_重合_B & AをBに重ねる & スリット空を既存空に組み合わせる \\
\hline A_付加_B & AをBに付加する & 新しいヴォールトを, 既存の屋根に付加寸る \\
\hline A_移動_B & AをBに移す & 彫刻を中庭に移動する \\
\hline \begin{tabular}{|l|} 
A_複製 B \\
\end{tabular} & AをBにコピーする & ファサードをガラス面に投影する \\
\hline A_分節 B & AをBで分ける & 内部空間をガラススで仕切る \\
\hline A_包圈B & AでBを覆う & ガラスで中庭をカバーする \\
\hline A 作用 $B$ & AがBに影響する & 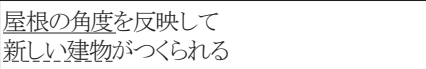 \\
\hline$A$ 包含 $B$ & AはBに含まれる & ドーム王冠内の空 \\
\hline $\mathrm{A} \underset{\mathrm{A} \text { 構成 }}{\longrightarrow} \mathrm{B}$ & AによってBが成り立つ & ガラスとルーバーによる新しいヴォールト \\
\hline$A \stackrel{\text { 同等 }}{\longrightarrow} B$ & AをBとする & 軍河沿いにつくられた古い工場 \\
\hline $\mathrm{A} \leadsto \stackrel{\text { 調和 }}{\longrightarrow B}$ & AとBは調和する & 新しいヴォールトが,市役所のヴオールト上 \\
\hline 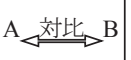 & Aに対してBである & 覈格な空間に対しデリケートな質感の石材を \\
\hline$A<$ 対置 $>B$ & AとBは向き合う & 本館と向き合って配置されたオユィス棟 \\
\hline $\mathrm{A}$ 燐接 $\mathrm{B}$ & AとBは接する & 南側の屋根の上にある空ケース \\
\hline
\end{tabular}




\section{3 改修過程の流れを表すフローチャートの作成}

改修計画全体の流れを捉えるために, 各改修事例から抽出した, 改修に関わる要素とその関係を表記規則に従って連結させ, 改修過 程を一連の流れとして体系化し，フローチャートを作成する（図 1 )。

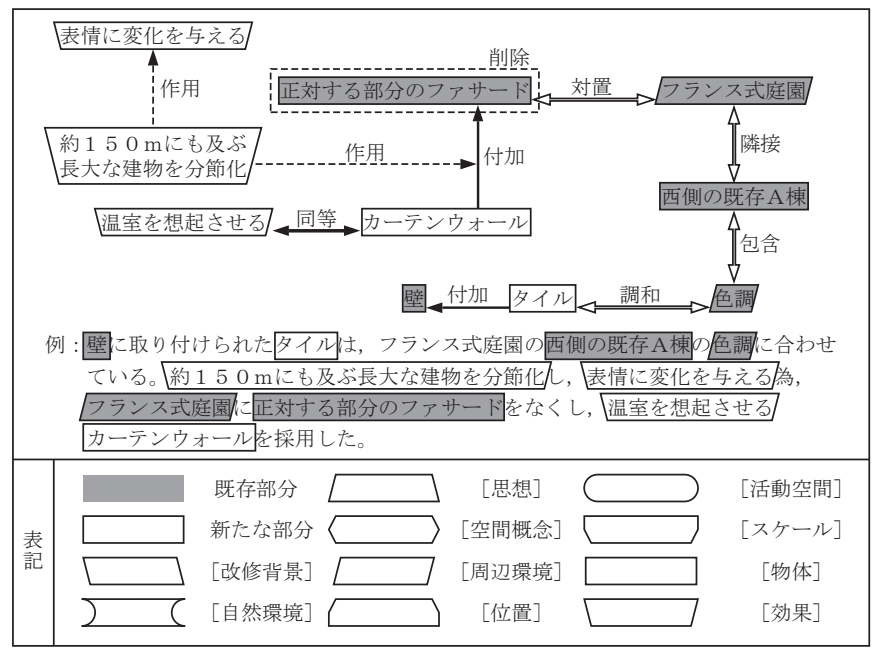

図 1 フローチャートの作成例

（No.118 千葉大学園芸系総合研究棟改修の一部）

\section{5. 〈付加価値〉の生成過程}

\section{1 〈付加価值〉の定義と生成過程の類型}

作成したフローチャートに示された内容を基に，改修に至る背景 や改修の要求を示寸部分を〈改修目的〉, 改修における建造物の既存 部分と改修部分の物理的な変化としての関係を示寸部分をく改修手 法〉, 改修を行う過程，または改修後において新たに導かれた効果 やイメージを示す部分をく付加価值〉と定義し，改修過程における 〈付加価值〉が導かれるまでの一連の流れを整理する。そして, く改 修目的 >, 〈改修手法〉, 〈付加価值〉の矢印のつながり方からく付 加価值〉の生成過程を類型化する。〈付加価值〉がどのように導か れているのかを把握するため, フローチャートのく付加価值〉に至 るまでの矢印のつながりを基準としてく改修目的〉, 〈改修手法〉, 〈付加価値〉の関係を分類した結果，〈付加価值〉の生成過程の類型 として類型 $\mathrm{I}$ 〜類型VIIの 7 タイプを得た。

\section{2 研究対象事例のく付加価值〉の生成過程}

研究対象として選定した 150 の事例を，〈付加価值〉の生成過程の 類型と共に一覧で示す (表 $3^{\text {注5) }}$ )。150の事例のうち，付加価值がみ られない類型VIIが 13 事例あり, これらは既存部分に価值を置いた点 に共通性がある。付加価值がみられる 137 事例に 180 の〈付加価值〉 を導く〈付加価值〉があった。類型 I は, 90 のく付加価值〉があり, 建築家がクライアントの提示したく改修目的〉を活用し, 発展させ, 単なる復旧や保全ではない建築作品としてのく付加価值〉を生成さ せる改修手法を用いる場合が多いことが読み取れる。類型 II は，7 の 〈付加価值〉があり, 類型 I の派生型といえる。類型而は，24のく 付加価值 >があり, 類型IVは, 42 のく付加価值 >がある。これらは, 建築家がクライアントの提示した〈改修目的〉とは別に〈付加価值〉 を導いている点で共通性がある。類型 $\mathrm{V}$ は 7 のく付加価值 $>$ があり, 類型VIは 8 の〈付加価值〉があるが, これらは, 導いたく付加価值〉 を高めるためにく改修手法〉を用いる点で共通性がある。

\section{3 <付加価値〉の生成過程の各類型の考察}

類型 I にあたる No.037 フランクフルト 21 のく改修手法〉には, 「プ ラットフォームレベルに，大規模な地下空間を付加する」という関 係が含まれていた。この関係から，「さまざまな方位から人のアクセ ス性を高められる」という，〈改修目的〉を満た寸効果のほか，「ホ 一ル全体の視覚的効果も立体的に高められる」という〈付加価值〉 が生まれている。これは,「プラットフォームレベル」と「大規模な 地下空間」が兼敉備える規模の大きさが，全てのく改修手法〉にお いて重要な役割を担っていると考えられる(図2)。

類型 I 〈改修目的〉 $\longrightarrow$ 〈改修手法〉 $\longrightarrow$ 〈付加価值〉 〈改修手法〉がく改修目的〉を満たすと同時にく付加価值〉を導く型

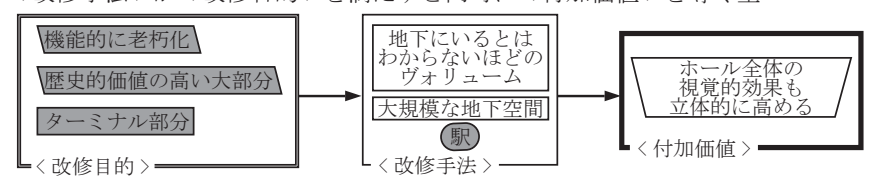

図 2 類型 I (例 No.037 フランクルト 21 の一部)

類型 II あたる No.141 ジルヴェルヴルートは，躯体の補修や設備 の更新，整備は行わず，既存のビル 2 棟を通路で連結しているのみ であるため，素材を用いた最小限の工夫により〈付加価值〉を意図 したことが伺える（図 3 ）。

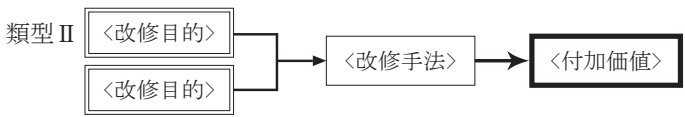

複数の〈付加価值〉を満たすく改修手法〉を用いることで, 〈付加価値〉を導く型
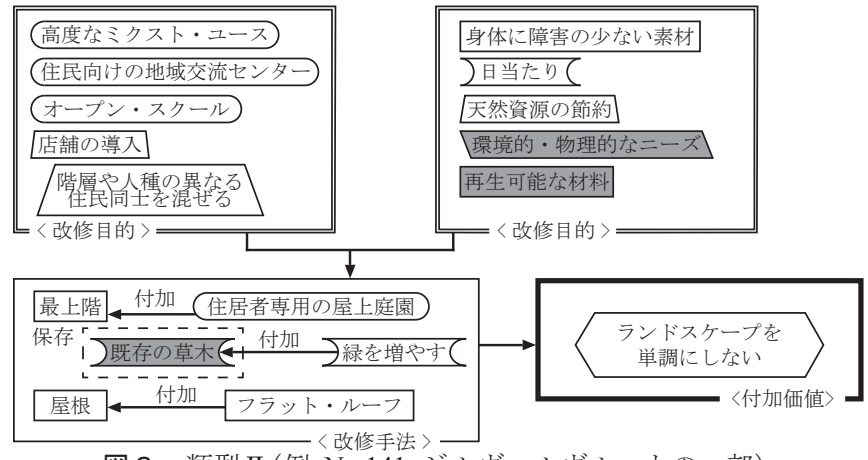

図 3 類型 II (例 No.141 ジルヴェルヴルートの一部)

類型而にあたる No.007 カピトリー二博物館は，発電所から博物館 へと用途変更する際の計画で考慮される, 動線計画や展示物の観賞 の仕方に奥行き感に関係をもたせることによって, 博物館の質を向 上させるく付加価値〉が導かれると考えられる（図 4 ）。

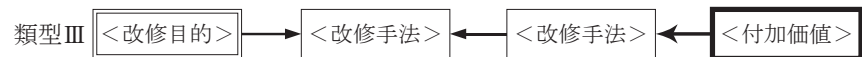
$<$ 付加価值 $>$ を優先し，<改修目的 $>$ を満たす<改修手法 $>$ と 関連づけるく改修手法 $>$ を誘発する型

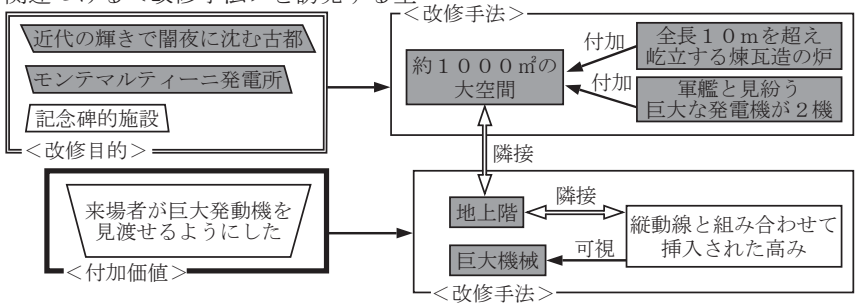

図 4 類型III (例 No.007 カピトリー二博物館の一部) 
表 3 対象とする近代建造物の改修事例

\begin{tabular}{|c|c|c|c|c|c|c|c|c|c|c|c|}
\hline No. & 類型 & 事例名 & 国 & 建造年 & 改修年 & No. & 類型 & 事例名 & 国 & 建造年 & 改修年 \\
\hline 001 & IV & チェレーレ・ビル & IT & 1905 & 1970s & 076 & $\mathrm{IV}+\mathrm{IV}$ & 交差点に建つ複合ビル & IR & $1960 \mathrm{~s}$ & \begin{tabular}{|l|}
1999 \\
\end{tabular} \\
\hline 002 & $\mathrm{I}$ & タラゴナ行政庁舎の改修 & SP & 1964 & 1987 & 077 & IV & ラ・クロータの住宅改築 & SP & 不明 & 1999 \\
\hline 003 & III & 水力学博物館・文化センター & SP & 1741 & 1988 & 078 & $\mathrm{I}+\mathrm{I}$ & 建築家のアトリエ & TU & 不明 & 1999 \\
\hline 004 & $\mathrm{I}$ & モウソン・タワー文化センター & GE & 1926 & 1990 & 079 & I & クローフォード美術館 & IR & 1724 & 2000 \\
\hline 005 & IV & 大英博物館 & UK & 1850 & 1990 & 080 & III+III & テート・モダン & UK & $19 \mathrm{c}$ & 2000 \\
\hline 006 & $I+I$ & クール美術館連絡通路 & SW & 1876 & 1990 & 081 & $\mathrm{I}$ & アパートメント・ハウス・D & IT & $19 \mathrm{c}$ & 2000 \\
\hline 007 & III & カビトリー二博物館 & IT & 1912 & 1990 & 082 & VII & レストラン「チャン・ガ」 & TU & 1903 & 2000 \\
\hline 008 & $\mathrm{I}$ & サン・シーロ・サッカースタジアム & $\mathrm{IT}$ & 1926 & 1990 & 083 & VII & 口ーマ市立現代美術館 & IT & $20 \mathrm{c}$ 初 & 2000 \\
\hline 009 & $\mathrm{I}$ & スイス銀行バーデン支店の増改修 & GE & 不明 & 1991 & 084 & VII & ワンズワース工場の改装 & UK & $1930 \mathrm{~s}$ & 2000 \\
\hline 010 & $\mathrm{I}$ & フィアット社リンゴット工場の再生 & $\mathrm{IT}$ & 1922 & 1992 & 085 & IV & 「ウェスト・エンド」公衆浴場 & NR & 1932 & 2000 \\
\hline 011 & II & コルトレークの家の増築 & $\mathrm{BE}$ & 不明 & 1992 & 086 & $\mathrm{IV+IV}$ & ボニエール出版社増築計画 & $\mathrm{SD}$ & $1940 \mathrm{~s}$ & 2000 \\
\hline 012 & I & スティーブン・ブルのビストロ・アンド・バー & UK & 不明 & 1992 & 087 & $\mathrm{I}$ & アスカー火葬場の霊安室 & $\mathrm{NR}$ & 1950後 & 2000 \\
\hline 013 & III & レストラン・ヴィニクスの改築 & SW & 不明 & 1992 & 088 & $I+I$ & ネッスル社屋の増改築 & SW & 1960 & 2000 \\
\hline 014 & VII & カン・カルデナル & SP & 不明 & 1992 & 089 & $\mathrm{I}$ & ガーラ邸の増築 & $\mathrm{BE}$ & 不明 & 2000 \\
\hline 015 & $\mathrm{I}+\mathrm{IV}$ & ヨックグリム・タウン・ホール & GE & $19 \mathrm{c}$ & 1993 & 090 & IV & 穀物サイロ増築棟の改装 & $\mathrm{NE}$ & 不明 & 2000 \\
\hline 016 & $I+I$ & オペラハウス & FR & 1831 & 1993 & 091 & $\mathrm{I}$ & 旧污染処理場に建つ集合住宅 & $\mathrm{NE}$ & 不明 & 2000 \\
\hline 017 & $\mathrm{I}+\mathrm{I}$ & 複合施設「クロイツストラッセ54」の改築 & SW & 1856 & 1993 & 092 & $\mathrm{I}$ & ミュージアム・クォーター・ウィーン & $\mathrm{AU}$ & 1854 & 2001 \\
\hline 018 & III & グネデインガー邸 & SW & 19c末 & 1993 & 093 & IV & 地域センター & $\mathrm{DE}$ & $1880 \mathrm{~s}$ & 2001 \\
\hline 019 & I & ドゥブ邸の改築 & GE & $1960 \mathrm{~s}$ & 1993 & 094 & $\mathrm{I}+\mathrm{I}+\mathrm{I}+\mathrm{III}+\mathrm{I}+\mathrm{I}$ & ガソメーターA棟 $(\mathrm{I}), \mathrm{B}$ 棟 $(\mathrm{I}+\mathrm{I}+\mathrm{IIII}), \mathrm{C}$ 棟 (I), D棟 $(\mathrm{I}) *$ & $\mathrm{AU}$ & 1889 & 2001 \\
\hline 020 & IV & ACOM社オフィスの改装 & $\mathrm{NE}$ & $1960 \mathrm{~s}$ & 1993 & 095 & $\mathrm{VI}$ & 新風館（SHIN-PUH-KAN） & JA & 1926 & 2001 \\
\hline 021 & IV & カトアン・ナティー社倉庫の改築 & BE & $19 \mathrm{c}$ & 1994 & 096 & $\mathrm{I}$ & 群馬県庁昭和庁舎 & JA & 1928 & 2001 \\
\hline 022 & II & 進化博物館 & FR & 1889 & 1994 & 097 & II & 学校の増築 & $\mathrm{NE}$ & $1930 \mathrm{~s}$ & 2001 \\
\hline 023 & VII & ゲシュヴィスター・レアルシューレ & GE & $1920 \mathrm{~s}$ & 1994 & 098 & IV & 文化・教育センターの増・改築 & $\mathrm{NE}$ & 不明 & 2001 \\
\hline 024 & III & グレッペンン小学校増築 & SW & 不明 & 1994 & 099 & $\mathrm{I}+\mathrm{IV}$ & カウリー・マナー・ホテルおよびスパ & UK & 1855 & 2002 \\
\hline 025 & VII & ソールド・スーターズ建築事務所別館 & $\mathrm{NE}$ & 不明 & 1994 & 100 & IV & リートベルグ美術館の増築計画 & SW & 1857 & 2002 \\
\hline 026 & III & バイクス・リョブレガートの地区評議会会場 & SP & 不明 & 1994 & 101 & III & 国立国会図書館 国際子ども図書館 & JA & 1906 & 2002 \\
\hline 027 & I & 交差点の集合住宅「プリンセンホーク」 & $\mathrm{NE}$ & $19 \mathrm{c}$ & 1995 & 102 & $\mathrm{I}$ & 立教大学第1食堂リニューアル & JA & 1918 & 2002 \\
\hline 028 & $\mathrm{~V}+\mathrm{V}$ & ビベラッ八市立図書館 & GE & 1894 & 1995 & 103 & IV & 大阪市中央公会堂 保存·再生工事 & JA & 1918 & 2002 \\
\hline 029 & $\mathrm{I}$ & ヴィッテル温泉休頽所の改修 & FR & $20 \mathrm{c}$ 初 & 1995 & 104 & $\mathrm{I}$ & アッピスベルク職業訓練施設の増改築 & SW & $1930 \mathrm{~s}$ & 2002 \\
\hline 030 & $\mathrm{I}$ & テアトロ・メトロポールの改修 & $\mathrm{SP}$ & 1908 & 1995 & 105 & $I+I$ & 金山町街並み交流サロン・ぽすと & JA & 1932 & 2002 \\
\hline 031 & $\mathrm{I}$ & \begin{tabular}{|l|} 
トウェンテ国立美術館改修 \\
\end{tabular} & $\mathrm{NE}$ & 1928 & 1995 & 106 & $\mathrm{I}+\mathrm{V}$ & プフルジアリアル複合集合住宅の改修 & SW & 1934 & 2002 \\
\hline 032 & VII & イラーニャの公共施設 & SW & $1950 \mathrm{~s}$ & 1995 & 107 & VII & イリャヴオ海洋博物館 & $\mathrm{PO}$ & 1937 & 2002 \\
\hline 033 & $\mathrm{I}+\mathrm{I}+\mathrm{VI}$ & ザルツブルグ北発電所第2棟 & $\mathrm{AU}$ & 1967 & 1995 & 108 & $\mathrm{I}$ & PARK SIDEGARDEN（七五三ビル） & $\mathrm{JA}$ & 1967 & 2002 \\
\hline 034 & $\mathrm{I}$ & チューリッヒベルク・ホテルの増改築 & SW & 不明 & 1995 & 109 & $\mathrm{I}$ & 京阪京橋駅ビルリニューアル計画 & JA & 1968 & 2002 \\
\hline 035 & $I+I$ & ベルギュンの納屋の改造 & SW & 不明 & 1995 & 110 & $\mathrm{I}$ & ルクセンブルグ国立歴史芸術博物館 & $\mathrm{RU}$ & 不明 & 2002 \\
\hline 036 & IV & バルディリ・イ・レイシャック・スクール & $\mathrm{SP}$ & 不明 & 1995 & 111 & $\mathrm{I}+\mathrm{I}$ & バース・スパ・プロジェクト & UK & 1775 & 2003 \\
\hline 037 & I & フランクフルト 21 & GE & $19 \mathrm{c}$ & 1996 & 112 & IV & ブレッドの住宅の「地下」増築 & SL & $19 \mathrm{c}$ & 2003 \\
\hline 038 & I & スウェイ・ヴィジュアル・アーツ・センター & UK & $19 \mathrm{c}$ & 1996 & 113 & VII & 網町三井俱楽部＼cjkstart保存・改修 & JA & 1913 & 2003 \\
\hline 039 & $\mathrm{I}$ & ロッテルダムの自然史博物館 & $\mathrm{NE}$ & 1851 & 1996 & 114 & $\mathrm{I}$ & 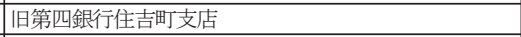 & JA & 1927 & 2003 \\
\hline 040 & $\mathrm{I}+\mathrm{V}$ & バスティーユ高架橋再利用計画 & FR & 1859 & 1996 & 115 & I & グラス・パレス & $\mathrm{NE}$ & 1934 & 2003 \\
\hline 041 & $\mathrm{I}$ & 二ュー・カールスベア彫刻美術館新展示室棟 & $\mathrm{DE}$ & 1888 & 1996 & 116 & $\mathrm{I}$ & ブリュッセル文化センター & $\mathrm{BE}$ & 1938 & 2003 \\
\hline 042 & $\mathrm{I}$ & トウェンテ国立美術館増改築 & $\mathrm{NE}$ & 1928 & 1996 & 117 & VII & ソーラー・パヴィリオン & UK & 1958 & 2003 \\
\hline 043 & III $+\mathrm{V}$ & 東京大学工学部1号館 & JA & 1935 & 1996 & 118 & IV & 千葉大学 園芸学系総合研究棟 改修 & JA & 1963 & 2003 \\
\hline 044 & II & ゼイラー邸の保存と修復 & $\mathrm{AU}$ & 戦前 & 1996 & 119 & IV & 東京大学 (本郷) 赤門総合研究棟 & JA & 1965 & 2003 \\
\hline 045 & I & モンテッソーリ保育園 & UK & $1960 \mathrm{~s}$ & 1996 & 120 & IV & アニエスガーデン銀座 & JA & 1971 & 2003 \\
\hline 046 & IV & カルミック美術館 & TU & 不明 & 1996 & 121 & $\mathrm{I}$ & 東京農業大学世田谷キャンパス10号館改修 & JA & 1975 & 2003 \\
\hline 047 & $\mathrm{I}+\mathrm{IV}$ & CM保険会社オフィス & $\mathrm{BE}$ & 不明 & 1996 & 122 & III & 興和広尾ビル＼cjkstart改修 & JA & 1979 & 2003 \\
\hline 048 & VI & ロイオス修道院のホテルとしての増改築 & PO & 不明 & 1996 & 123 & III & 三重県立美術館 & JA & 1982 & 2003 \\
\hline 049 & $\mathrm{I}+\mathrm{I}+\mathrm{I}$ & ニッコロ・パガニー二音楽堂 & IT & $19 \mathrm{c}$ & 1997 & 124 & $\mathrm{I}+\mathrm{IV}$ & スイス・アルペン・クラブのチェルバ小屋 & SW & 不明 & 2003 \\
\hline 050 & $\mathrm{III}+\mathrm{VI}$ & ハートルダム寺院の西側フアサードの改築 & FR & 1860 & 1997 & 125 & $\mathrm{I}$ & コインブラ美術学校西棟改修 & PO & 不明 & 2003 \\
\hline 051 & $\mathrm{I}$ & リール市立美術館 & FR & 1895 & 1997 & 126 & IV & アゼンタオンの住宅 & $\mathrm{PO}$ & 不明 & 2003 \\
\hline 052 & IV & マルメ・シティ・ライブラリー & SD & 1900頃 & 1997 & 127 & $\mathrm{VI}$ & ブカッティ・オートモービルS・A・S 本社 & FR & 1788 & 2004 \\
\hline 053 & $\Pi+\mathrm{V}$ & 国立現代アートスタジオ「ル・フレノア」 & FR & $1920 \mathrm{~s}$ & 1997 & 128 & IV & カスターニエンバウムの古いヴィラ & SW & $1860 \mathrm{~s}$ & 2004 \\
\hline 054 & IV & クラークンウェルのスタジオ・ビル & UK & $1930 \mathrm{~s}$ & 1997 & 129 & I & ロイド・ホテル & $\mathrm{NE}$ & $1920 \mathrm{~s}$ & 2004 \\
\hline 055 & IIII & ノー・ピクニック・デザイン・スタジオ & SD & $1930 \mathrm{~s}$ & 1997 & 130 & $\mathrm{VI}+\mathrm{I}+\mathrm{VI}$ & パブリシス・ドラッグストア & FR & 1926 & 2004 \\
\hline 056 & $\mathrm{I}+\mathrm{IIII}+\mathrm{I}$ & \begin{tabular}{|l|l|} 
八リュ斎場 \\
\end{tabular} & FI & $1930 \mathrm{~s}$ & 1997 & 131 & VII & 一橋大学 兼松講堂 & $\mathrm{JA}$ & 1927 & 2004 \\
\hline 057 & $\mathrm{I}+\mathrm{IV}$ & トゥウェンテエ工科大学カルスラーン学生寮 & $\mathrm{NE}$ & 1965 & 1997 & 132 & III & 高樹町センタービル 而震補強 & JA & 1965 & 2004 \\
\hline 058 & VII & 世界貿易センタービルディング & JA & 1970 & 1997 & 133 & IV & 阿智村図書館＼cjkstart増築・改修 & $\mathrm{JA}$ & 1979 & 2004 \\
\hline 059 & II & フェルトキルヒに建つ集合住宅の車庫と納屋 & $\mathrm{AU}$ & 1970初 & 1997 & 134 & $\mathrm{IV}+\mathrm{IV}$ & 列柱ホールとオフィス & IT & 1980 & 2004 \\
\hline 060 & $\mathrm{IV}+\mathrm{IV}$ & バンク・レストラン & UK & 不明 & 1997 & 135 & $\mathrm{I}$ & サレミ大聖堂およびアリチア広場の再生 & IT & 不明 & 2004 \\
\hline 061 & $\mathrm{I}$ & ナンシー見本市センター & FR & 不明 & 1997 & 136 & $\mathrm{~V}$ & シャモソンにある住宅の改修 & SW & 1814 & 2005 \\
\hline 062 & IV & ジャンフランコ・フィレ本社 & IT & 1902 & 1998 & 137 & $\mathrm{I}$ & プスティニア & IR & 1820 & 2005 \\
\hline 063 & IV & オスカー・ラインハルト美術館の増改築 & SW & 1915 & 1998 & 138 & $\mathrm{I}+\mathrm{IIII}+\mathrm{IV}$ & \begin{tabular}{|l|l} 
「ルネスホール」旧日銀岡山支店 \\
\end{tabular} & $\mathrm{JA}$ & 1922 & 2005 \\
\hline 064 & $\mathrm{I}+\mathrm{VI}$ & クッパースミューレ・ミュージアム & GE & 1916 & 1998 & 139 & I & 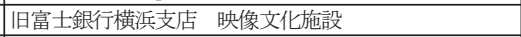 & JA & 1929 & 2005 \\
\hline 065 & $\mathrm{I}$ & リッソーニ・デザイン事務所 & IT & $20 \mathrm{c}$ 初 & 1998 & 140 & $\mathrm{I}+\mathrm{I}+\mathrm{I}$ & 小金井カントリー俱楽部 クラブハウス & $\mathrm{JA}$ & 1937 & 2005 \\
\hline 066 & VII & ジェングルキョイの住宅改装 & $\mathrm{TU}$ & 不明 & 1998 & 141 & II & ジルヴェルヴルート & $\mathrm{NE}$ & 1960 & 2005 \\
\hline 067 & $\mathrm{I}$ & ヘリフォード芸術センター & UK & 不明 & 1998 & 142 & IV & ケブランティンスの教会 & PO & 不明 & 2005 \\
\hline 068 & I & タック・タワーの増改築 & $\mathrm{BE}$ & 不明 & 1998 & 143 & IV & ジェミニ・レジデンス & $\mathrm{DE}$ & 不明 & 2005 \\
\hline 069 & $\mathrm{~V}$ & ナショナル・ギャラリー増築計画 & $\mathrm{SL}$ & 不明 & 1998 & 144 & IV & グラン・ドュック・ジャン近代美術館MUDAM & $\mathrm{RU}$ & $18 \mathrm{c}$ & 2006 \\
\hline 070 & $\mathrm{IV}+\mathrm{IV}$ & エバースヴアルデ工業学校の図書館 & GE & $19 \mathrm{c}$ & 1999 & 145 & III & ラウンド八ウス & UK & 1846 & 2006 \\
\hline 071 & $\mathrm{I}+\mathrm{IIII}$ & メゾン・コニャック・ジェイ & SW & 19c後 & 1999 & 146 & III & ロペス・デ・エレディア・ワイナリー & SP & 1910 & 2006 \\
\hline 072 & $\mathrm{I}$ & ライヒスターク & GE & 1894 & 1999 & 147 & $\mathrm{I}$ & アトリウム・ビル & FR & $1960 \mathrm{~s}$ & 2006 \\
\hline 073 & I & ダーウェント外科医療センター & UK & $1930 \mathrm{~s}$ & 1999 & 148 & $\mathrm{I}$ & ブルーノ・バーグル小学校増築 & GE & $1970 \mathrm{~s}$ & 2006 \\
\hline 074 & $\mathrm{I}$ & 京都芸術センター & $\mathrm{JA}$ & 1931 & 1999 & 149 & III & フライターグ・フラグシップ・ストア & SW & 不明 & 2006 \\
\hline 075 & $I+I$ & ヴァーサ大学学生寮 & FI & $1950 \mathrm{~s}$ & 1999 & 150 & IV & |゙ーゼル美術館とラウンレンツバウの改築 & SW & 1926 & 2007 \\
\hline
\end{tabular}

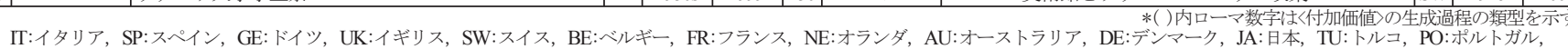

$\mathrm{SD}$ :スウェーデン, FI:フインランド, SL:スロヴェニア, IR:アイルランド, NR:ノルウェー, RU:ルクセンブルグ 
類型IVにあたる No.001 チェレーレ・ビルは，躯体の補修や設備の 更新，整備は行わず，既存のビル 2 棟を通路で連結するのみである ため，素材を用いた最小限の工夫によりく付加価值〉を意図したこ とが伺える。既存の内装をそのままに空間構成を変化させた点で特 殊である(図 5 )。

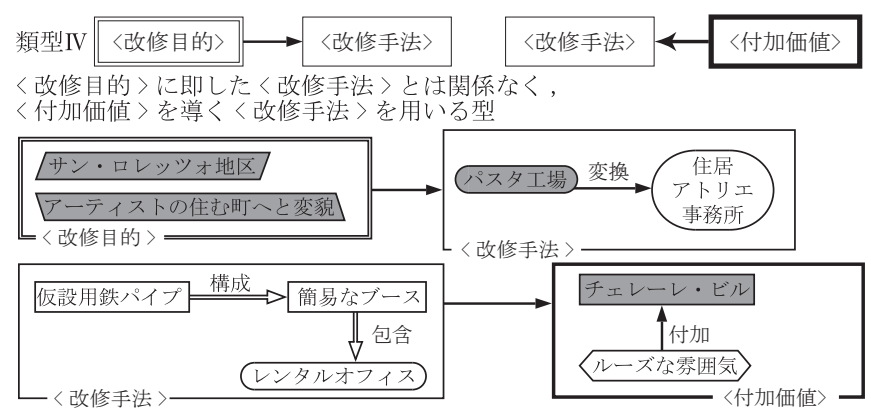

図 5 類型IV(例 No.001 チェレーレ・ビルの一部)

類型 Vにあたる No.028 ビベラッ八市立図書館は，木造 6 階建て大 型倉庫の図書館への用途変更で，4階以上をスタッフ空間とするく改 修手法〉と, 3 スパン分の床板の削除と 6 階吹き抜けの増設, 大型卜 ップライトの増設というく改修手法〉で，内部空間を広げるく付加 価值〉を生成したことが伺える（図6）。

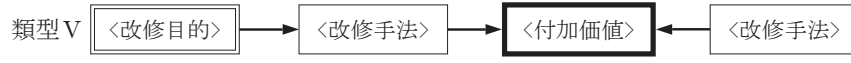
導いたく付加価值〉を高めるために，さらにく改修手法〉を用いる型

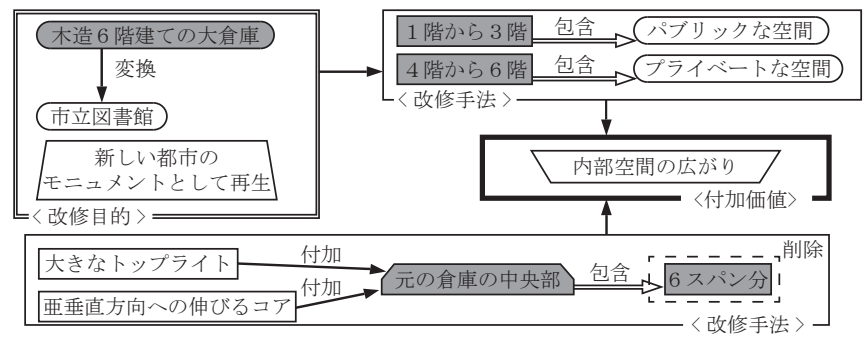

図 6 類型 $\mathrm{V}$ (例 No.028 ビベラッハ市立図書館の一部)

類型VIにあたる No.033 ザルッブルク北発電所第 2 棟は，発電所 の躯体をそのままに，スタッフ用の施設へと空間構成を計画し直す 〈改修目的〉から, 新しい構造体の上部をガラスで覆う〈改修手法〉 により，解放感というく付加価值〉が生成され，その結果，細長い

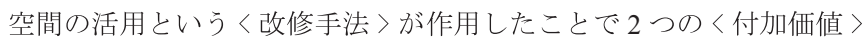
が導かれたことが伺える（図 7 )。

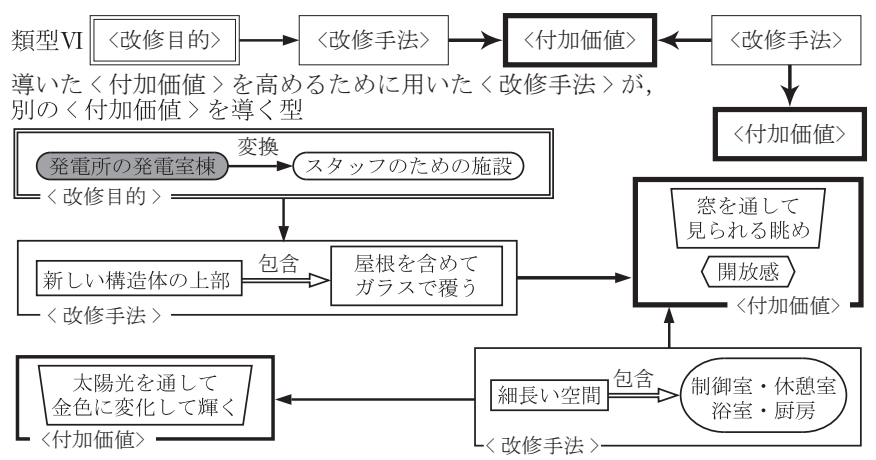

図 7 類型VI(例 No.033 ザルツブルク北発電所第 2 棟の一部)
類型VII型にあたる No.014 カン・カルデナルは，過去と現在，古い ものと新しいもの，材質の違う二つの材料など，対照する二つのバ ランス関係を探求や, 自然環境の変化を知覚できる内部空間の探求 といったす心゙てのく改修手法〉により，古い農家の価值を再発見す る新しい住宅に導き出すことが可能であったと考えられる（図 8 )。

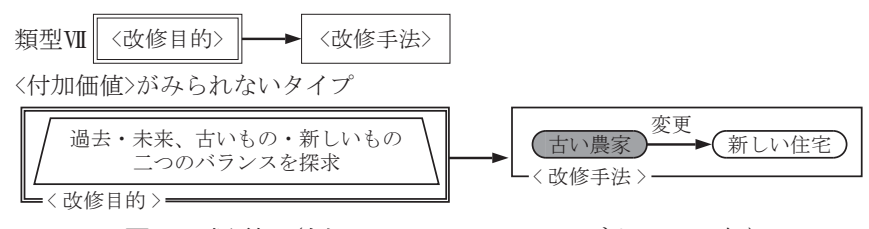

図 8 類型VII (例 No.014 カン・カルデナルの一部)

\section{6. 〈改修手法〉の類型}

改修によって導かれるく付加価值〉は具体的な建築行為としての 建造物の増改築によって導かれる。そこで, 改修による建造物の具 体的な変化を把握するため, 作成したフローチャートの内容の特に 改修における建造物の物理的な変化としての既存部分と改修部分の 関係を示寸部分である〈改修手法〉を類型化した結果，〈改修手法〉 の類型として類型 $\mathrm{a} \sim \mathrm{m}$ の 13 種類の分類を得た（表 4 ）。

表 4 〈改修方法〉の類型

\begin{tabular}{|c|c|}
\hline 類型a & 既存の[スケール]が新たな [物体]に作用 \\
\hline 類型b & 既存の[空間概念]を変更・強調 \\
\hline 類型 $\mathrm{c}$ & 既存の[物体]の特徵が改修過程にて表出 \\
\hline 類型 $\mathrm{d}$ & 新たな[物体]による相互関係 \\
\hline 類型 $\mathrm{e}$ & 新たな $[$ 物体 $]$ と, 既存の [物体]が対比 \\
\hline 類型 $\mathrm{f}$ & [改修背景]が，〈改修手法〉に作用 \\
\hline 類型 $\mathrm{g}$ & [思想]が〈改修手法〉に作用 \\
\hline 類型h & [周辺環境]が〈改修手法〉に作用 \\
\hline 類型 $\mathrm{i}$ & [活動空間]が〈改修手法〉に作用 \\
\hline 類型 $\mathrm{j}$ & [自然環境]が〈改修手法〉に作用 \\
\hline 類型 $\mathrm{k}$ & 改修過程にて発見した問題が〈改修手法〉に作用 \\
\hline 類型1 & 既存部分を保存することで〈改修手法〉に作用 \\
\hline 類型 $\mathrm{m}$ & 因果関係なし \\
\hline
\end{tabular}

類型 $\mathrm{a}$ は，既存の高さ，幅，スパンなどの［スケール］が新たな 物体に作用している事例が挙げられる。類型 $\mathrm{b}$ は，空間と空間導入 部の結合, 空間相互のレベル差の創出, 開放的な眺めや採光の獲得 等, 既存の [ 空間概念] を際立たせる事例が挙げられる。類型 $\mathrm{c}$ は, 既存の壁が境界の役割を高める, 既存の棟と新築棟が遠近法的な感 覚をもたらす外部空閒をつくりだす等の事例が挙げられる。類型 $\mathrm{d}$ は，壁の素材を付加することで建造物全体に新たな特性を加えてい る事例や，既存のファサードをガラス面で覆うことで，仮想空間の ような写像を出現させている等の事例が挙げられる。類型 $\mathrm{e}$ は, 既 存部分と改修部分が中庭を囲い対比する事例や，屋根の木材とレン ガの色を対比させる事例等が挙げられる。類型 $\mathrm{f} は$ は, 景観計画上, 周 囲と一体的なファサードを形成させる事例が挙げられる。類型 $\mathrm{g}$ は, 建築家の意図として, 既存部分の厳格さと改修部分の自由さを得る 事例や，開放感や奥行き感等の空間的魅力をつくる事例等が挙げら れる。類型 $\mathrm{h}$ は, 周辺の建造物, 川や公園等の [周辺環境 ]により, 水平方向につながりをもたせる事例や, 横に広がるファサードの外 形を強調しない事例等が挙げられる。類型 $\mathrm{i}$ は, 空中通路, 地下トン ネルなど人の [ 活動空間 ] がく改修手法〉で作用する事例が挙げら れる。類型 $\mathrm{j}$ は, 光や色をガラスのファサードを用いて強調する事例 や，パーゴラ回廊という緩衝帯を用いて落ち着きある閲覽室をつく 
りだす事例等の [環境条件]を変化させるく改修手法〉が挙げられる。 類型 $\mathrm{k}$ は，木製パネルでファサードを覆うことで，外壁面の表情が 周辺から独立しないようにする事例が挙げられる。類型 1 は, 建造物 のもとの特性を保つために, 既存のコンクリート壁と緑樹を残寸事 例が挙げられる。類型 $\mathrm{m}$ は, 改修過程でく改修手法〉とは関係ない 酒落た外観というく付加価値〉が生まれた事例が挙げられる。

\section{7. 〈付加価値〉の生成過程と〈改修手法〉の関係}

改修によるく付加価值〉の生成過程を把握するため, 導かれたく付 加価值〉に着目し, 各改修事例の個別考察を行った。その結果, 〈付 加価値〉は, 形態, 構造, 空間構成, 用途, 省エネ, 保存, 一体性, 対比，景観，印象の 10 種類に類型化できた（表 5 )。

表 5 〈付加価値〉の類型

\begin{tabular}{|c|c|}
\hline 類型 & 定義 \\
\hline [形態] & 既存部分へのヴォリュームの追加などで創出される付加価值 \\
\hline [構造 $]$ & 補強や保存のための構造体の変更に伴う付加価值 \\
\hline [空間構成] & 室配列·空間導線•利用方法の変更による機能面の付加価值 \\
\hline [用途] & 外部の取り込みなど、機能の更新により用途を拡張する付加価值 \\
\hline [省エネ] & 地球環境保全につながる付加価值 \\
\hline [保存] & 既存部分の歴史的な特徵を活かす付加価值 \\
\hline [一体性] & 新旧を調和させ、特定の部分を一体的に見せる付加価值 \\
\hline [対比] & 既存部分と新築部との矛盾を逆手に取った対照による付加価值 \\
\hline [景観] & 建造物や周辺の風景への視線の操作による概観的な付加価値 \\
\hline [臥象] & 象徵性や想起性の操作による深層心理的・形而上的な付加価値 \\
\hline
\end{tabular}

そして,これら導かれたく付加価值〉の類型, 前章までに得られたく付 加価值〉の生成過程の類型，〈改修手法〉の類型から，横軸にく付加 価值〉の生成過程の類型, 縦軸にく改修手法〉の類型として整理し, 分析することで (図 $9^{\text {注 } 6)}$ ), 〈付加価值〉の導かれ方を考察する。

\section{1 [形態]}

連続したアーチ型の形態や，屋根が折れ曲った形態などを創出す る〈付加価值〉は, 既存部分に大屋根を付加する〈改修手法〉や, 教会の天井部分のアーチとヴォールトの頂部間に張られたケーブル に一対のカーテンを支持させ，サインなどを取り付けるときに役立 たせるというく改修手法〉により導かれている。ここでは, ヴォリュー ム，屋根などの既存部分の形態が改修過程に作用しく付加価值〉を 導いている。

\section{2 〔構造〕}

1 階部分を RC 造にするというく改修手法〉により，既存の木造 5 階分をその上にもち上げる，既存天井の栍目にしっくりと収まるポ ジションを与えるといったく付加価值〉は類型 I と類型 $\mathrm{c}$ が大部分 を占めている。ここでは, 既存の構造部の特徴が改修過程にあらわ れている。

\section{3 [空間構成〕}

既存の 1 階部分を 2 階部分と捉えて計画し各階を特徽づける, 部 屋毎に異なる照明を設けることで個々の特徵を強める等，既存の 空間のイメージを強調するく改修手法〉bや，床スラブの削除に よる空間の連続性の獲得，壁面の部分削除による新たな動線の創 出等, 既存空間の特性を表出させるく改修手法 >c によってく付 加価值〉を導いていた。また，室配列，動線，利用方法を考慮 した室用途の更新，通路と中庭の隣接関係によるシークエンス 等，複数の室や内外空間が関連してく付加価值〉を導いていた。く付 加価值 $>$ 生成過程では，「独自の動線」「「屋内の移動」等，人の移

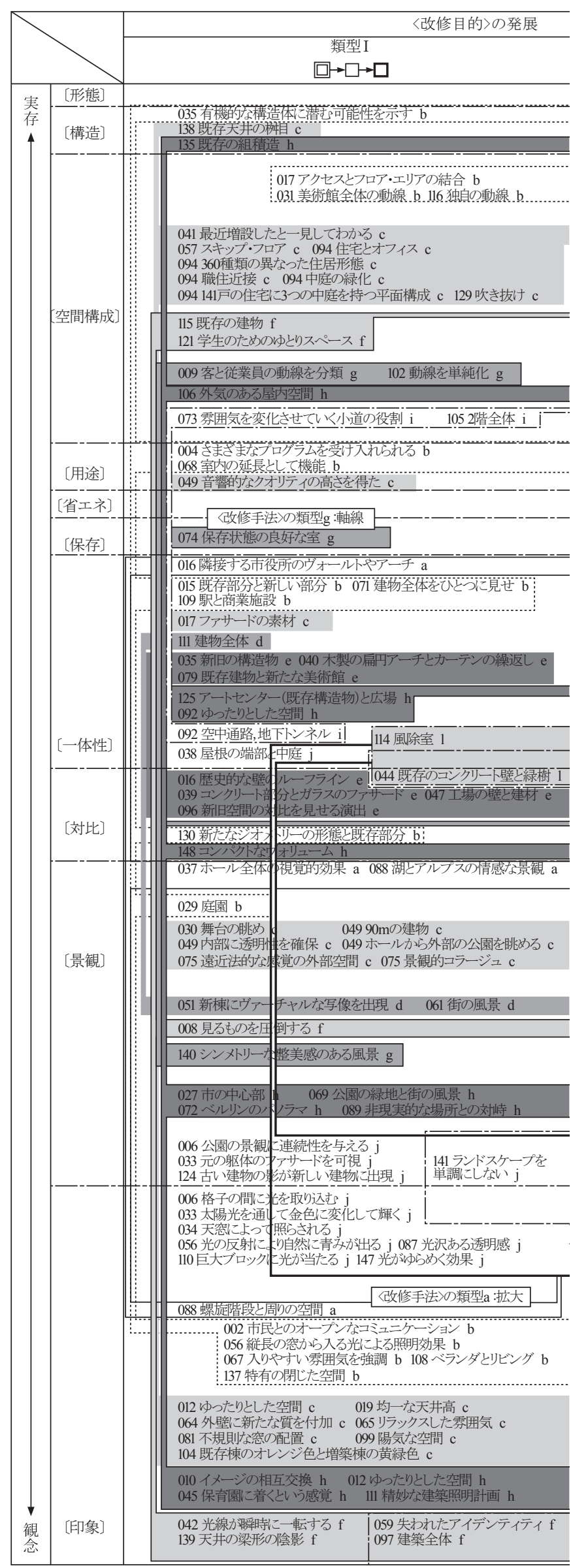




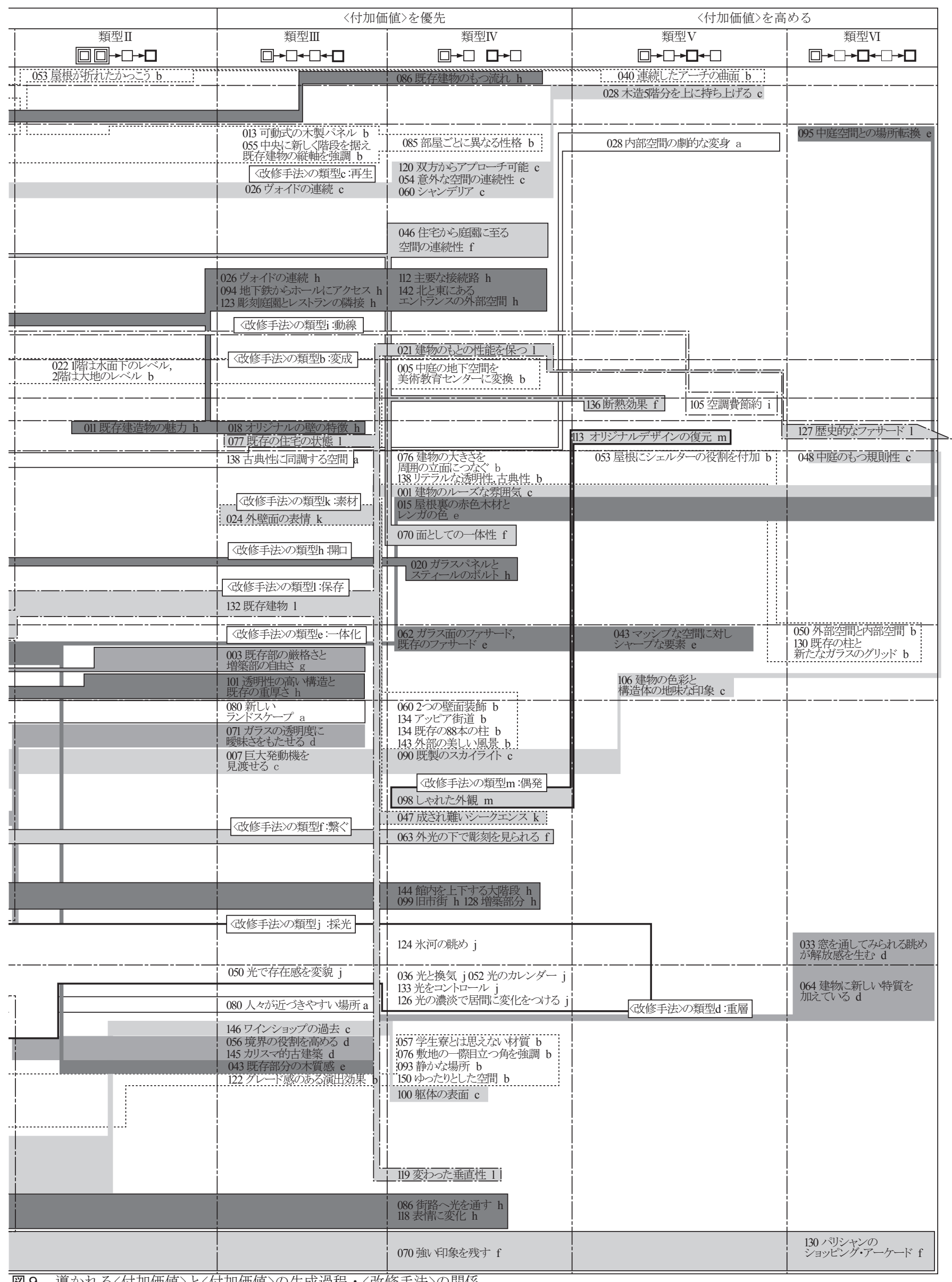


動に関わる部分に関係する改修が類型 I の大半を占めた。また, 複 数の室に連続する「吹き抜け」や，「地下空間と地上部分」の連結 等, 空間の連続性に関わる部分に関係する改修が類型IVの大半を占 めた。

\section{4 〔用途〕}

様々なプログラムを受け入れられる, 室内の延長として機能する

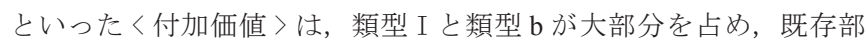
分の用途が，中庭を中心とした動線や既存部分を改修部分に納める といったく改修手法〉により実現されていた。ここでは，既存部分 の機能の更新や用途変更のためにレベル差の利用や新しい機能の付 加などのく改修手法〉同士が空間的，視覚的に関係をもつことでく付 加価値〉が導かれている。

\section{5 [省エネ〕}

空調費節約, 断熱効果といったく付加価值〉は, No.136では, 通 気量の確保, 再生可能なエネルギー源の利用, 屋上にソーラーパ ネルを付加する等の〈改修手法〉により導かれている。No.105 で は，朽廃直前であった郵便局を文化施設へと変更することで町づ くりの拠点とするというく改修目的〉を，グループ活動における 家具の新たな利用方法の提案によって満たしている。また，個室 を無くし既存の間取りを全て利用者に開放するというく改修手 法〉に加え，維持管理は自治体が行い，一般管理は婦人グループ の自主運営に委补るという運営方式まで計画することによっても 〈改修目的〉を満たしている。この事例は, 建築コストや空調コスト の削減といった省エネを，非建築的な仕掛けである家具の新たな利 用方法や個室を無くした大空間を個別化する引き戸を設置するく改 修手法〉によって導いている。両事例ともに, 比較的小規模な建造 物の利用面積を, 増築を行わずに増加させており, 日本と欧州に共 通のく改修目的〉によってく付加価值〉が導かれている。

\section{6 〔保存〕}

既存部分の壁の特徴や歴史的なファサードを活かす〈改修手法〉 が，既存建造物の魅力を保つ〈付加価值〉を導いている。ここでは， 既存部分の壁，ファサード，空間の特徴を活かすという〈改修目的〉 を満たすことで生まれるく改修手法〉同士の関連により〈付加価值〉 を導いている。No.127では, 既存のドアなどを部分的に残し, 既存 の建造物を煉瓦造とすることをく改修目的〉とし，ファサードは大 きな開口に, 馬屋を展示室に改修するく改修手法〉が用いられている。 この事例は, 保存を目的としたく改修手法〉を用い, 現在の建築条 件を活用したく付加価值〉の創出に重点を置いている。

\section{7 [一体性]}

既存部分と改修部分, 既存部分と [ 周辺環境 ]との調和等, 特定 の部分を一体的に見せるといったく付加価值〉は, 類型 I と類型IV が大部分を占め, 床面と壁面仕上の統一や柱スパンの拡大等, 構造 体の表面や位置を意図したく改修手法〉により導かれていた。No.111 では, 既存部分と増築部分の間の段差によって, 建造物全体の重層 性を導いているが, No.125では, 改修により周辺広場と既存建造物 の床を段差なく隣接させ, 開口で周辺広場と建造物の一体性を導い ていた。前者は, 敷地が傾斜地であり, 増築部分によって建造物を 連結させる意図があったことから，既存部と増築部の間に重層性を 設けることで全体の一体性を導いていた。また，後者は，隣接する 広場が密集した建造物に囲まれ，街路からアクセスできず閉鎖的で
あったため, 一体性を導いていた。〈付加価值〉を導く過程におけ るこれらの相違点は, 建造物の立地環境の差が, 形となって増改築 部分に現れたと考えられる。また, No.035 では, 躯体の保存, 省工 ネルギーをく改修目的〉としたため, 新旧の躯体を層状に一体化し, 地域固有の材料を使用寸ることで, 材料の経年変化による新旧の建 造物の調和を導くという, 構法面に価值を付加した点で特殊である。

\section{8 〔対比〕}

既存の柱によるグリッドと新たなガラスのグリッドによる対 比, 透明性の高い構造と既存の重厚感による対比といったく付加 価值〉は, 類型 $\mathrm{I}$ と類型 $\mathrm{b}$ が大部分を占めている。また, 既存部 を尊重するという [思想] の優先や, 既存建造物の色彩の強調等, 多様なく改修手法〉によって対比が導かれていた。特に, 既存部 分における壁, 柱, ファサード, 開口部等, 建造物を構成する上 で必要不可欠なものが, 形態, 色彩, グリッド等の改修部分と対 比関係を築いていた。このことから，既存部分の躯体を保存する 過程において，既存の躯体と改修部分の関係が，壁，床，柱等の 物理的な付加だけでなく, 様々なく付加価值〉を導く要因となっ ているといえる。No.003 では, 水車を建設当時の状態に復元する 〈改修手法〉と復元に伴う新設部分の〈改修手法〉の対比に価值をお くことで, 水車の形体を外観に反映させ, 印象を強める〈付加価值〉 を導いていた。この事例は, 建造時の形態の復元を最重要としたため, 〈改修手法〉同士を対比させることで，〈改修目的〉と形態面のく付 加価值〉を関連づけた事例であるといえる。

\section{9 〔景観〕}

過去の眺めの復元や夕陽による建物の影を意図した風景の創造 等, [改修背景] や自然現象が〈改修手法〉に作用し, 〈付加価值〉 を導いていた。また, 〈付加価值〉の生成過程は, 類型 I と IVが多く 類型 $\mathrm{V}$ はみられない。類型 I では, No.008 での巨大なコロンが「見 るものを圧倒する」, No.072での「ベルリンのパノラマ」をドームか ら眺めるというように, 〈改修手法〉によって建造物の広範囲に価値 が付加される過程を示している。類型 $\mathrm{V}$ が見られないのは, 〔景観】 という眺望的なく付加価值〉に対して, 更にく改修手法〉を用いて 〈付加価值〉を高めようと試みると, 建造物全体の構成が変わり, 矛 盾が生じるためと考えられる。建造物の眺めや周辺への眺望に価値 を付加して改修計画を行う際は， [ 改修背景] やく改修目的〉との関 係を保つことを意図することが望まれる。

\section{10 [印象]}

No.057では，入り口のドアをガラス製にし，内部に白い大理石 を用いるく改修手法〉で「学生寮とは思えない」〈付加価值〉を導 き, さらにNo.065 では「リラックスした雰囲気」等の〈付加価值〉 を, 〈改修手法〉類型 $\mathrm{c}$ によ導いていた。印象〕は, 類型 I のよ うにく改修手法〉を用いた際に導かれるだけではなく, 既存部分之 [ 周辺環境] の関係, また, 既存の内部空間から改修後の建造物を意 図して計画的にも導かれている。特に, No.110では, 広場上部の天 然石に光が当たることで, エントランスの存在感を際立たせ, 国内 に残る石造の要塞を思い起こすという象徵的なく付加価值〉を導い ている。これは, 〈改修目的〉に即して, 既存の延床面積を 2 倍に拡 張する際, 広場の大部分を地下に移動し, 更に地上広場と地下広場 の空間の連続性を保ったことで, 光の入り方や建造物の空間構成に 作用し，存在感の強調を意図した過程がうかがえる。 


\section{8. 結論}

本研究のまとめとして, 物理的な変化としてのく改修手法 >a $\sim \mathrm{m}$ を, その生成するく付加価值〉と, 〈付加価值〉の生成過程の類型, フローチャートに示された内容から再考察したい。類型 $\mathrm{a}$ は, 一体性, 景観, 印象の〈付加価值〉を生成し, 〈付加価值〉の生成過程の類型 は I と II のみだが, 内容をみると, 物理的に拡大寸る〈改修手法〉 と考えられる。類型 $\mathrm{b}$ は, 保存, 省エネ以外のすべての〈付加価值〉 を生成し，〈付加価值〉の生成過程の類型もす心゙てにわたるが，内容 的には既存建造物を変成するく改修手法〉と考えられる。類型 $\mathrm{c}$ は, 空間構成・印象・景観の〈付加価值〉に集中し，〈付加価值〉の生成 過程の類型は I に集中し, 内容的には既存建造物の再生に主軸を置 〈〈改修手法〉と考えられる。類型 $\mathrm{d}$ は, 主に眺望, 印象のく付加 価值〉を生成し, 〈付加価値〉の生成過程の類型は I と III とVIのみで, 内容的には新たな物体を重層して新一新の相乗効果を発揮させるく改 修手法〉と考えられる。類型 $\mathrm{e}$ は，基本目的である対比のほかに, 一体性，印象のく付加価值〉も生成しており，新旧を対比させるた めに, 物理的には新旧を一体化する必要があり, 内容的にも一体化 の〈改修手法〉と考えられる。類型 $\mathrm{f}$ は, 背景とく改修手法〉の関連 だが, No.097 では増築部を地下で繋ぐことで, 既存部の独立性を保ち, No.121 では, 全体をウッドデッキで繋ぎ，学生のゆとりスペースを 生成している。No.008 は，コーナー部に巨大なコロンを繋ぐことで 見るものを圧倒する。背景との関連づけは物理的に「繋ぐ」く改修手 法〉で解決される。類型 $\mathrm{g}$ はいずれも, 活用したいが復元も重視す る相克した思想が物理的く改修手法〉を「軸線」の工夫に導いてい る点で非常に興味深い。No.003では水車を活用かつ復元したいので, 水車全体の直線性を利用して各室を鉛直軸で貫き，既存部の厳格さ と増築部の自由さを導いた。No.009 ゙は，エントランス動線を新旧 部位に振り分けて客と従業員の動線を分離し, No.102では旧食堂に 含まれていた配膳・返却動線を付带部分の新厨房に負担させて動線 を単純化し，No.140 は，建て替えであり改修ではないが，旧棟の記 憶の継承という思想が，エントランスの奥行等の軸線を重視するく改 修手法〉が シンメトリーな整美感のある風景を生んでいる。類型 $\mathrm{h}$ は，周辺環境という思想がく改修手法〉に影響を与えるが，物理的 には開口部を操作する改修手法と考えられる。類型 $\mathrm{i}$ は，活動空間が 〈付加価值〉に影響した例で, 生成数は少ないが, 物理的なく改修手 法〉は動線に集中している。類型 $\mathrm{j}$ は, 景観, 印象の〈付加価值〉を 生成し, 〈付加価值〉の生成過程の類型は広く分布し, 光と眺望を操 作するための, 採光の〈改修手法〉と考えられる。類型 $\mathrm{k}$ は改修中 に見つけた問題を克服した事例で，2事例のみだが，いずれも外装の 素材の〈改修手法〉である。No.024では, 村の反対側の建物との調 和の必要を感じ，外装を木製パネル化した。No.047 でもデザインの 過程で既存部分の豊かさを発見し, 粗い壁の感触と繊細な建材とい う外装の物理的く改修手法〉が，成され難いシークエンスというく付 加価値〉を導いている。類型 I も 8 事例のみで, 分布に特徵は無いが, 保存を主軸にしたく改修手法〉と考えられる。類型 $\mathrm{m}$ は, 1 事例の みであり, 〈改修手法〉と関係が無い偶然のく付加価值〉生成は特殊 な例外といえる。以上を総合して，〈改修手法〉の類型 $\mathrm{a} \sim \mathrm{m}$ を端 的に表現した（表 6 ）。

以上より, 本研究では, 近代建築の改修事例をく付加価值〉とい う観点から整理し, 具体的な増改築の〈改修目的〉と〈改修手法〉
表 6 考察を考慮した<改修手法 >の命名

\begin{tabular}{|l|l|}
\hline 類型 $\mathrm{a}$ & 桩大 \\
\hline 類型 $\mathrm{b}$ & 変成 \\
\hline 類型 $\mathrm{c}$ & 再生 \\
\hline 類型 $\mathrm{d}$ & 重層 \\
\hline 類型 $\mathrm{e}$ & 一体化 \\
\hline 類型 $\mathrm{f}$ & 繋ぐ \\
\hline 類型 $\mathrm{g}$ & 軸線 \\
\hline 類型 $\mathrm{h}$ & 開口 \\
\hline 類型 $\mathrm{i}$ & 動線 \\
\hline 類型 $\mathrm{j}$ & 採光 \\
\hline 類型 $\mathrm{k}$ & 素材 \\
\hline 類型 1 & 保存 \\
\hline 類型 $\mathrm{m}$ & 偶発 \\
\hline
\end{tabular}

と導かれるく付加価値〉との関係の特性について論考した。く付加価 值〉の類型，〈付加価值〉の生成過程の類型，〈改修手法〉の類型の 関係を知見として示すことを試みた。今後は，本研究の結果を踏ま えたうえで, 〈付加価值〉を生成するく改修手法〉の本質に迫る研究 を行っていきたい。

注

注 1）建築大辞典によれば，近代建築は 19 世紀以来の建築の総称であるが， 近代特有の材料, 構造, 機能を考慮しながら, 歴史的様式とは違った 独自の建築形式を実現するようになるのは 1910 年代ないし 20 年代の ことに属する。それ故, この語は狭義には 1920 年代を中心とする国際 建築の動向を指寸と定義されている。本研究での近代とは, 歴史の時 代区分のひとつで，近世よりも後，現代よりも前の時期を指す時期で ある 1920 年代を中心とした 19 世紀後半から 20 世紀半ばまでの時期と して扱っている。

注 2) 本研究での価値とは, 歴史的価值, 社会的価值, 文化的価値, 建築的 価值などそれぞれの意味をもっており，これらが複合的な意味をもっ ているものとして価値という用語を用いている。

注 3）建築専門誌を研究資料とするにあたり，発行される地域による文化や 風土，言語などの差異が文章の表現，意味に影響すると考えられる。 そのため本稿では, 文章の表現, 意味に対する影響を考虑して研究資 料としての一定の水準を保つため日本で発行された建築専門誌を报う。 そして, 近代建造物の改修が積極的に行われ始め, 国内外の改修事例 が多く掲載されるようになった 1990 年以降の建築専門誌『a + u』, 『SD』, 『新建築』、『近代建築』を研究資料とし改修事例を収集した。日本国 内だけではなく海外建築の動向にも詳しいこれらの建築専門誌を扱う ことは, 改修に伴い建造物に導かれる付加価値と空間構成の方策を把 握する上でも，基礎的な資料になると考える。また，研究資料とした 建築専門誌に掲載される記述には和訳文も含まれるが，建築の知識を 十分にもつ日本の建築家や建築評論家が翻訳を行ったものであるため, 分析には有用であると考える。以上の視点から建築専門誌から改修事 例を収集した結果，欧米諸国と日本の改修事例が大半を占めていたた め, 本稿では欧州と日本の事例を対象とする。また, 収集した改修事 例の中から，建て替えの事例，災害により再建された事例，プロジェ クト案・コンペ案のように実際に建設されていない事例，図面・文書 など分析に必要な情報が不明である事例を除外し，150 事例に研究対象 と寸る改修事例を絞った。建造年が不明であり，建造年による近代建 造物の判断が出来ない事例については, 近代建築様式の特徵（ファサ 一ドに表れているアーチ空やフランス空等）を文章・図面・写真から 読み取ることで判断した。本研究では，これら 150 の事例に対する作 品解説文を主として分析を行い, 補完的に図面・写真を用いている。

注 4）分析対象とした改修事例の説明文は, 設計者及び解説者による説明文 を研究対象とする。解説者による説明文は以下の改修事例が該当する。 木下央, チェレーレ・ビル, 『SD Review 2005』, 2005.12, pp.91-92 宮脇勝, 大英博物館, 『SD』0010, 2000.10, pp.48-51 ■木下央, カピ トリー二博物館, 『SD Review 2005』, 2005.12，pp.78-79 Ш宮脇勝, サ ン・シーロ・サッカースタジアム、『SD』0010，2000.10，pp.98-99 ם宮 脇勝，オペラ・ハウス，『SD』0010，2000.10，pp.24-27 ם宮脇勝，進 
化博物館, 『SD』0010, 2000.10, pp.64-67ם宮脇勝, ビベラッハ市立 図書館, 『SD』0010，2000.10, pp.19-22 ם宮脇勝, フランクフルト 21, 『SD』0010, 2000.10, pp.38-39 ם宮脇勝, 東京大学工学部 1 号館, 『SD』 0010, 2000.10, pp.70-71 宮脇勝, 国立現代アートスタジオ「ル・フ レノア」, 『SD』0010, 2000.10, pp.93-95ロオットー・カップフィンガ 一,フェルトキルヒに建つ集合住宅の車庫と納屋, 『 $\mathrm{a}+\mathrm{u} 』 332,1998.5$, pp.76匹小林克弘, ジャンフランコ・フェレ本社, 『SD Review 2005』, 2005.12, pp.95-96 宮脇勝, クッパースミュレ・ミュージアム，『SD』 0010, 2000.10, pp.60-63 日椎橋武史, リッソーニ・デザイン事務所, 『SD Review 2005』, 2005.12, pp.75-76 ם宮脇勝, テート・モダン, 『SD』 0010，2000.10，pp.52-53 日三田村哲哉，ローマ市立現代美術館，『SD Review 2005』, 2005.12, pp.83 ם 宮脇勝, ガソメーター,『SD』0010, 2000.10, pp.28-33 ロフベルトゥス・アダム, リートベルグ美術館の増 築計画, 『a+u』434, 2006.11, pp.80

注 5）表 3 では，フローチャートの数をく付加価值〉の生成過程の数とし, 複数のく付加価值〉が導かれる類型VIの場合には，表 3 では，最初に 導かれるく付加価值〉を示寸こととした。

注 6）第 7 章の分析について, 本稿は近代建造物の改修において導かれる付 加価值について論考するものである。そのため, 第 5 章の〈付加価值〉 の生成過程の類型における類型VIIについてはく付加価值〉がみられな かったものであるため, 第 7 章の図 9 には記載しないものとする。また, 図 9 で記載したく改修手法〉の類型の表記では, 複数の〈改修手法〉 を用いるく付加価值〉の生成過程の類型III VIでは, 最初に導かれるく付 加価值〉を導くく改修手法〉の類型を表記した。

\section{参考文献}

1）小原誠：改修の円滑化のための建物各部位の構成について 建物のライ フサイクルに対応する構法計画の研究, 日本建築学会計画系論文報告 集第361号, pp.31-41，1986.3

2）曾根陽子：公共建築における用途変更の傾向と要因 公共建築の機能 変更に関する研究 (その1), 日本建築学会計画系論文集 第403 号, pp.53-62, 1989.9

3）曽根陽子：用途変更における出入口の変更と工事グレードとの関係に ついて 公共建築の機能変更に関する研究 (その 2), 日本建築学会計画 系論文報告集 第413 号, pp.39-48，1990.7

4）齊藤哲也，八木幸二：転用された歷史的建造物の用途分類と地区別特 性 ミラノ市における歷史的建造物の転用に関する研究 その 1 , 日本 建築学会計画系論文集 第 526 号, pp.147-152, 1999.12

5）齊藤哲也，八木幸二：歴史的建造物の転用における改修方針と建築的 介入 ミラノ市における歴史的建造物の転用に関する研究 その 2 , 日 本建築学会計画系論文集 第 546 号, pp.97-104, 2001.8

6）松村秀一，村上心，梁成旭，西村秀之：再生工事の経済・組織的成立 条件に関寸る事例研究 マス八ウジング期に建設された集合住宅の再生 手法に関寸る国際比較研究 その 2, 日本建築学会計画系論文集 第 524 号, pp.139-145, 1999.10

7）佐藤孝一，松村秀一，西瑠衣子：コンバージョンの実施可能性評価に 関する研究 オフィスビルから集合住宅への用途変更, 日本建築学会計 画系論文集 第 597 号, pp.31-36，2005.11

8）渋谷達郎，岸本達也：欧州及び日本におけるサステナブル建築のデザ イン手法とその特性に関寸る研究，日本建築学会環境系論文集 第 589 号, pp.99-105, 2005.3

9）吉田信之 : $a+u 9401-0710, a+u, 1994-2007$

10）長谷川愛子 :SD，鹿島出版会，9701-0010，1997-2000

11）長谷川愛子：コンバージョン・デザインの可能性, SD Review 2005, 鹿 島出版会, 2005

12）吉田信之：リノベーション特集, 新建築 0510 , 新建築社, 2005

13）松田邦昌，千川一宏：特集 リニューアル/コンバージョンによる都市 再生, 近代建築 0301, 近代建築社, 2003

14）松田邦昌, 千川一宏 : 特集 リニューアル/建築のライフサイクル価值 を考える, 近代建築 0409, 近代建築社, 2004

（2012年 9 月10日原稿受理，2013年 4 月10日採用決定） 